\title{
DIE BESOEK VAN PROF. DR. HERMAN DOOYEWEERD.
}

Voordat hy na ons toe gekom het, het ons hom al geken - uit sy werke; en ons, dosente en studente, het met daardie werke geworstel. Want hulle is groot in getal en omvang, groots van opset en konsepsie en swaar en gewigtig van inhoud, wetenskaplike graniet; maar wie hulle bemeester het, het ' $n$ kostelike rykdom van nuwe, omvattende en indringende kennis hom eie gemaak. Meer as een van ons het verwag dat prof. dr. H. Dooyeweerd, geoordeel na sy werke, enigsins ongenaakbaar en styf sou wees. Ons het hom egter leer ken as 'n vriendelike, innemende, menslike mens. Hy het hom as persoon onder ons bemind gemaak en van ons 'n vriend geword-ten spyte van die feit dat hy maar net sewe dae onder ons was.

Maar dit was dae van 'n besondere soort, die dae naamlik van die selfstandigwording van ons universiteit, dae wat ons nie sal vergeet nie, dae waarin ons op ons geskiedenis teruggekyk het en nuwe en verdiepte geesdrif vir die ideale en toekoms van ons universiteit in ons harte voel opstyg het, dae waarin die enkele duisende besoekers van alle dele van ons land die bande van ons inrigting met al sy ondersteuners opnuut verstewig het, grootse dae waarin geluk- en seënwense van alle kante ons toegestroom het en heerlike dae waarin ons met 'n dankgebed op 
ons lippe kon feesvier-al het ons ook feesgevier met 'n traan in ons oog oor die afsterwe van ons onvergeetlike Rektor.

Ons gas uit Holland was gedurende hierdie heuglike dae egter nie as 'n gewone besoeker by ons nie, maar as 'n verteenwoordiger van die Hollandse Universiteite en wel in die eerste plek van die Vrije Universiteit van Amsterdam waarvan hy Rector Magnificus is. Deur hom het Holland saam met ons fees gevier en die Dietse bande opnuut verlewendig; deur hom het die Hollandse universiteite in ons vreugde gedeel en ons geluk toegewens op die pad wat voor ons lê; deur hom h?t Calvinistiese Holland ons opnuut sy belangstelling in ons getoon en ons blydskap sy blydskap gemaak; en deur hom het besonderlik ons suster-universiteit, die Vrije Universiteit, nuwe bande met ons nuwe P.U. gesmee en daardie innige en hartelike seëngroet oorgebring wat wortel in die geloofsgrondslag van ons beide universiteite.

Wat die laaste betref: „Het zijn niet alleen banden van innige stamen cultuurverwantschap, die daarbij spraken, het is bovenal de geestelijke band der geloofsgemeenschap en de band van eenzelfde gereformeerde wetenschapsopvatting, die onze beide universiteiten op de nauwst denkbare wijze samenbindt .... Het zijn niet rossen en ruiters, die ons bij het najagen van het ideaal eener christelijke reformatie der wetenschap ter overwinning zullen voeren. Het is uitsluitend de innerlijke drijfkracht van Gods Geest in Christus Jezus, in onze wetenschapsbeoefening en de wetenschappelijke vorming onzer studenten steeds meer onder zijn beslag moet krijgen, zullen wij in de volle blijdschap en het volle vertrouwen des geloofs voorwaarts gaan .... Moge onze zuster te Potchefstroom in dié kracht des geloofs haar nieuwe taak beginnen en moge zij in dié goddelijke kracht groeien en gedijen en daardoor voor volk en wetenschap tot zegen zijn". (Prof. Dooyeweerd in ons Gedenkprogram).

Toe die berig tot ons gekom het dat die V.U. 'n afgevaardigde na ons feeste sou stuur, was ons ontroerd, te meer omdat die V.U. nie oor groot somme beskik nie en nes ons besonderlik afhanklik is van die gawes en offers van sy ondersteuners onder wie nie baie rykes tel nie. Meer as een het dan ook uitgeroep: „Is dit nie pragtig nie!" Ek sien nog hoe bly en dankbaar prof. Postma was toe dié berig hier angekom het. Uit hierdie daad van die V.U. spreek 'n hartetaal wat in ons harte innige weerklank gevind het. Die P.U. sal hierdie vriendskapsbewys nie vergeet nie. En wat nog meer sê is dat die V.U. juis sy Rektor hierheen afgevaardig het. 
Reeds met prof. Dooyeweerd se aankoms in ons land het ons ' $n$ behoefte gevoel om ons waardering met die daad te toon, en 'n viertal van ons dosente het per motor na Palmietfontein gegaan-nie om ons gas hierheen te bring nie, want hy sou eers na Pretoria gaan-maar om hom daar namens ons inrigting en ondersteuners welkom te heet.

In ons feesprogram is een middag spesiaal ingeruim vir 'n rede van ons eregas voor raadslede, dosente, studente en vriende van ons inrigting. Hy het ons toegespreek oor "Die Idee van 'n Christelike Universiteit en Christelike Wetenschap." Hoe gemaklik en boeiend het hy nie gepraat nie en-as ons aan sy werke dink-hoe verstaanbaar! Dit was 'n besielende, gedagteryke pragrede en die gehoor het aan sy lippe gehang en gevoel dat sy beginsel, strewe en probleme ons beginsel, strewe en probleme is, dat ons by mekaar hoort en één in grondslag en ideaal is.

Die hoogtepunt van sy besoek was egter toe hy (naas o.a. verteenwoordigers van ons owerheid, van die Ger. Kerk, van al die universiteite in ons land) sy boodskap en gelukwense offisieel voorgedra het en wel namens die Hollandse Universiteite en in besonder namens die V.U. Dit was kostelike oomblikke van kragtige en besielende woorde deur die skare van 3,000 in die stilte van intens luisterende swye opgevang. Die minute-en minute-lange, luide ovasie wat die skare as antwoord op sy seëngroet gebied het, was 'n harte-antwoord.

Ons wou voor en na die feeste graag nog drie toesprake (w.o. 'n kollege) van ons hooggeleerde gas gehad het. Maar omdat hy enigsins ooreis hier aangekom het, het ons dit verminder tot een openbare toespraak, gereël deur die studentekorps Veritas Vincet en wel oor „Die Historisme en die Maatstawwe van Ontwikkeling en Beskawing." Hierdie intellektuele fees het geëindig (na die bedankingswoord) met die aanbieding aan hom van ' $n$ in leer gebonde Korps-publikasie as herinnering aan sy optrede voor Korps.

Van besondere betekenis was die talryke gesprekke wat ons as kollegas gedurende sy sewe-daagse besoek met hom geniet het en al kon ons nie alle probleme stel en nie alles bespreek wat ons graag wou gestel en bespreek het nie, wat ons van hom gekry het was altyd interessant, stimulerend en leersaam. Dat ons van ons kant hom soveel as moontlik ingelig het oor ons Suid-Afrikaanse toestande en probleme is-siende veral die misverstande daaroor in die buitenland-vanselfsprekend. Aan hierdie persoonlike kontakte met hom sal ons altyd met waardering terugdink, te meer omdat hy so'n aangename persoonlikheid is.

Prof. Dooyeweerd (wat ook die hoë eer te beurt geval het om tot lid van die Koninklijke Academie benoem te word) is ' $n$ besonder begaafde 
en geniale geleerde. Hij is juris en wysgeer van naam. Oorbekend is sy "Wijsbegeerte der Wetsidee" en ander werke. Hy bied ons hier in 'n originele, indringende, koene konsepsie 'n omvattende en tot in besonderhede deurwrogte Calvinistiese wysbegeerte wat 'n vergelyking met ander grootse wysgerige stelsels met eer kan deurstaan. En dit sê geweldig veel, veral as ons daaraan dink dat die Westerse wysbegeerte meer as twee en 'n half millennia oud is, terwyl die Calvinistiese wysbegeerte (as ons sy begin sou reken met die verskyning van Herman Bavinck se "Wijsbegeerte der Openbaring") noueliks 'n halwe eeu oud is. Die meesterlike wysgerige arbeid van Dooyeweerd (en saam met hom van sy swaer, Vollenhoven) is m.i. dan ook 'n evenement in die geskiedenis van die wysbegeerte.

As ek hier ' $n$ persoonlike getuienis mag gee dan is dit dat ek self besonder veel van hierdie uitnemende denkers geleer het, nie alleen van hul intensiewe analises van byna ontelbare vraagstukke en van hul vlymend skerpe en tot op die wortels gaande kritiek van andersdenkendes nie, maar veral ook hoe om 'n Calvinistiese wysbegeerte te bou wat tegnies ' $n$ wysbegeerte en geen teologie is nie. Maar- en dit veral maak 'n hartlike samewerking moontlik-al sien ek nie alle vraagstukke soos hulle nie, al kan ek moeilik sommige wysgerige sieninge van hulle onderskrywe en al sou ek graag plek-plek ons Calvinistiese wysbegeerte anders wil bou, hulle heel meningsverskille in eie kring welkom. Prof. Dooyeweerd het hier herhaaldelik gesê dat hy geen wysgerige skool wil vorm nie, dat alle Calvinistiese wysgere, nieteenstaande hulle onderlinge meningsverskille in betrokke punte, moet saamwerk en dat wat ons saambind ons gemeenskaplike taak en ons gemeenskaplike geloofsgrondslag is. Vir hierdie gesonde en ruime. standpunt eer ons hom. Dat sy besoek ook vir my persoonlik en as wysgeer besonder veel beteken het, spreek dan ook vanself, al sou ek graag meer geleentheid vir wysgerige samesprekinge wou gehad het.

Prof. Dooyeweerd het nie net Potchefstroom besoek nie, maar ook Pretoria, Johannesburg, Bloemfontein, Stellenbosch, Kaapstad en Grahamstad en aan die betrokke universiteite die groete oorgebring van die universiteite van Holland. Orals is hy hartlik ontvang.

In 'n betreklike kort tyd het hy baie van ons land gesien, baie (en veral akademiese) kontakte gemaak en baie van ons landsen volks-probleme leer ken. Hy besef dat hy te kort hier was om 'n gesaghebbende oordeel oor al ons ingewikkelde vraagstukke te vorm. Maar hy het die nodige simpatieke instelling om ons met ons probleme en met die oplossings wat ons vind in die regte gees te verstaan. Sy 
321.

besoek aan ons sal ook vir ons in dié sin baie beteken dat hy misverstande oor ons en ons optrede waar nodig en aangewys in die buitenland sal regstel.

Mag sy besoek tot ryke seen strek van ons Dietse bande, van die akademiese kontakte tussen Holland en Suid-Afrika, meer in besonder nog van ons onderlinge Calvinistiese verhoudings en veral van 'n hartelike samewerking tussen ons beide suster-universiteite! Die hand wat die V.U. deur die besoek van prof. Dooyeweerd aan die P.U. uitgestrek het neem ons aan om dit nie weer los te laat nie.

Mag ook prof. Dooyeweerd in sy so belangrike arbeid rykelik geseën word!

Potchefstroom.

H. G. STOKER. 